\title{
Immunological responses of rabbits to various somatic and secreted antigens of Vibrio cholerae after intra- duodenal inoculation
}

\author{
S. KABIR*
}

National Institute of Public Health, Bilthoven, The Netherlands

\begin{abstract}
Summary. The immunological responses of rabbits after intra-duodenal immunisation with live Vibrio cholerae organisms were studied in various body fluids. Serum, bile and intestinal samples were collected from rabbits at different times (1-8 weeks) after immunisation. Three different extracts from the small intestine were prepared. At first the small intestine was washed with saline (method A). Later, ultrasonic lysates were prepared from epithelial cells separated with citrate (method B) and of mucosal tissue above the muscularis layer (method $\mathrm{C}$ ). All had agglutinating activities against $V$. cholerae strains belonging to both biotypes (classical and el tor) and both serotypes (Ogawa and Inaba). Levels in intestinal extracts, sera and bile of antibodies to somatic (lipopolysaccharide and cell-surface proteins) and secreted (cholera toxin and neuraminidase) antigens of $\boldsymbol{V}$. cholerae were determined by an enzyme-linked immunosorbent assay. All contained antibodies to these antigens; although both IgA and IgG were present, IgA predominated. Serum and bile samples contained mainly IgG and IgA respectively. Immunoblotting studies demonstrated that the antisera contained antibodies to most cell-surface proteins and to cholera toxin. Cell-surface proteins appeared to be the major cross-reacting somatic antigens of $V$. cholerae.
\end{abstract}

\section{Introduction}

Vibrio cholerae is a gram-negative bacterium which colonises the small intestine. Its cells possess somatic components that include lipopolysaccharides (LPS) and surface proteins that are immunogenic in man and in experimental animals (Majumdar et al., 1981; Kabir, 1982, 1983a, b). V. cholerae cells also secrete products such as cholera toxin and neuraminidase (De and Chatterje, 1953; Ada et al., 1961; Kabir et al., 1984). Despite extensive research, an effective vaccine providing long lasting immunity against cholera has not been developed and understanding of cholera immunology remains limited. Although cholera is a disease of man, detailed investigation of the immune status of human beings is not possible, partly on ethical grounds. Therefore, there have been several recent attempts to develop an animal model in which cholera immunology can be studied with minimal artificial manipulation. Spira et al. (1981) developed an adult rabbit model in which live $V$. cholerae cells

Received 10 Jul. 1986; accepted 1 Sep. 1986.

* Correspondence should be sent to Dr S. Kabir, Tobaksspinnargaton $5 \mathrm{nb}, 11736$ Stockholm, Sweden. were introduced into the small intestine and a permanent ligature applied to the caecum to prevent resorption of fluid. Guinée et al. (1985) modified this model and observed that even simple inoculation of live $V$. cholerae cells into the upper duodenum protects rabbits against homologous and heterologous challenge for several weeks. The present investigation measured immunological responses of rabbits given live $V$. cholerae cells intraduodenally by the method of Guinée et al. (1985) to somatic antigens and to certain exoproducts.

\section{Materials and methods}

\section{Bacterial strains}

V. cholerae strains 395 (Ogawa, classical), C5 (Ogawa, el tor), 48 (Inaba, classical) and N-16961 (Inaba, el tor) were used.

\section{Media}

Two types of culture media were used: (i) peptonewater $(3 \%$ solution of peptone, $p \mathrm{H} 7.4)$ prepared as described by Burrows et al. (1965); (ii) semi-synthetic medium prepared as described by Evans et al. (1973). 


\section{Growth conditions}

$V$. cholerae cells were grown aerobically at $25^{\circ} \mathrm{C}$ in semi-synthetic medium and the number of viable cells was measured by a plate count.

\section{Animals and surgical procedures}

Outbred male conventional New Zealand white rabbits (ENKI, The Netherlands), c. $2.5 \mathrm{~kg}$, were used. They were starved, but were allowed to drink water, for $24 \mathrm{~h}$. Before surgery, each rabbit was given $0.05 \mathrm{ml}$ of a muscle relaxant and held under a local anaesthetic. The small intestine was exteriorised and $V$. cholerae $C 5$ cells $(10 \mathrm{ml}$, $10^{4} / \mathrm{ml}$ ) were introduced into the duodenum about $10 \mathrm{~cm}$ distal to the stomach. The injection point was closed with sterile glue. Any fluid leakage was checked with a cotton swab plated on to agar. The small intestine was replaced and the incision closed. The animal was monitored for overt diarrhoea. Animals that survived for $120 \mathrm{~h}$ were considered to have survived the infection. Such animals were killed at different times afterwards and their sera, bile and intestines collected.

\section{Collection of samples}

(a) Serum was separated from blood samples obtained by ear-vein puncture, inactivated by incubation at $56^{\circ} \mathrm{C}$ for $30 \mathrm{~min}$, and stored at $-20^{\circ} \mathrm{C}$ until use.

(b) Bile was collected from each rabbit by puncturing the gall bladder with a 23-gauge needle and withdrawing fluid with a syringe.

(c) Intestinal samples (i) saline washings. After killing a rabbit, a portion of the intestine, between the end of the stomach and the junction of ileum and caecum, was isolated and cut into small portions. The lumen was washed with cold phosphate-buffered saline (PBS) three times. The combined washings were brought to a volume of $200 \mathrm{ml}$ and centrifuged at $3000 \mathrm{~g}$ for $30 \mathrm{~min}$. The supernate was ultrasonicated for $10 \mathrm{~min}$. The material so obtained was concentrated 20 -fold by dialysis against polyethylene glycol $6000(40 \% \mathrm{w} / \mathrm{v})$. The material was stored at $-20^{\circ} \mathrm{C}$ until use.

(ii) Citrate extract. After thorough washing in PBS, the intestinal lumen was filled with a buffer containing sodium citrate in PBS $(0.096 \mathrm{M}$ sodium chloride, $0.008 \mathrm{M}$ potassium phosphate, $0.027 \mathrm{M}$ sodium citrate, $0.0056 \mathrm{M}$ dibasic sodium phosphate, $0.0015 \mathrm{M}$ potassium chloride, $p H$ 7.2) (Stern and Jensen, 1966) with penicillin 100 units/ $\mathrm{ml}$ and streptomycin $100 \mu \mathrm{g} / \mathrm{ml}$. After incubation for $15 \mathrm{~min}$ at $37^{\circ} \mathrm{C}$ the cells were released from the mucosa by gently pressing the filled intestinal segments. The contents of the lumen were drained and were ultrasonicated for $10 \mathrm{~min}$. The sonicate was centrifuged at $3000 \mathrm{~g}$ for $10 \mathrm{~min}$ and the clear supernate was concentrated 20 fold by dialysis against polyethylene glycol $6000(40 \%$ $\mathrm{w} / \mathrm{v})$ and stored at $-20^{\circ} \mathrm{C}$ until use.

(iii) Tissue extract. After washing with the citrate buffer, the small intestine was cut into small pieces, everted and the superficial tissue was separated from the muscularis with a scalpel. The suspension was homogenised, suspended in PBS and ultrasonicated. The sonicate was centrifuged at $3000 \mathrm{~g}$ for $10 \mathrm{~min}$ and the clear supernate was concentrated by dialysis against polyethylene glycol $(40 \% \mathrm{w} / \mathrm{v})$ and stored at $-20^{\circ} \mathrm{C}$ until use.

\section{Agglutination studies}

$V$. cholerae cultures were adjusted to $10^{10}$ cells $/ \mathrm{ml}$ with PBS. Two-fold dilutions of the test material (serum, bile or intestinal samples) were added to equal volumes of bacteria in microtitration plates and the agglutination pattern was recorded after incubation for $2 \mathrm{~h}$.

\section{Isolation of LPS}

LPS extracts from Ogawa and Inaba serotypes of $V$. cholerae were prepared by the phenol-water procedure of Westphal et al. (1952). The crude LPS was further purified by repeated untracentrifugation at $105000 \mathrm{~g}$ (Westphal and Jann, 1965). Their protein contents were measured by the method of Lowry et al. (1951) with bovine serum albumin as the standard.

\section{Extraction of cell-surface proteins of $V$. cholerae}

Cell-surface proteins were extracted from $V$. cholerae cells with EDTA- $\mathrm{NaCl}$ as described by Kabir (1983a), Briefly, $2 \mathrm{~g}$ (wet weight) of $V$. cholerae cells was washed twice with cold EDTA- $\mathrm{NaCl}(5 \mathrm{ml} ; 0.12 \mathrm{M}$ EDTA, $0.77 \mathrm{M}$

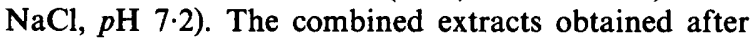
centrifugation $(20000 \mathrm{~g}, 30 \mathrm{~min})$ were concentrated by negative pressure dialysis against PBS and again centrifuged for $15 \mathrm{~min}$. The resultant supernate was used for further investigation.

\section{Cholera toxin}

This was supplied by List Biological Laboratories, Campbell, CA, USA (Lot CVX-013).

\section{Neuraminidase}

This was obtained from Serva Fine Biochemicals, Heidelberg, Germany (Lot 30116).

\section{Enzyme-linked immunosorbent assay (ELISA)}

Antibody levels against LPS, cell-surface proteins, cholera toxin and neuraminidase in bile, serum and intestinal samples were determined by ELISA in microtitration plates. With the exception of cholera toxin, plates were coated directly with the optimal doses of the antigen, determined by preliminary experiments. Thus, LPS, cell-surface proteins and neuraminidase were used at concentrations of $1 \mu \mathrm{g} / \mathrm{ml}, 50 \mu \mathrm{g} / \mathrm{ml}$ and $2 \mu \mathrm{g} / \mathrm{ml}$ respectively. Antibodies to cholera toxin were determined by the ganglioside-ELISA as described by Sack et al. 
(1980). Briefly, plates were coated with $\mathrm{G}_{\mathrm{M} 1}$ ganglioside $1 \mu \mathrm{g} / \mathrm{ml}$ at $20^{\circ} \mathrm{C}$ for $16 \mathrm{~h}$. After washing, the plates were coated with cholera toxin $1 \mu \mathrm{g} / \mathrm{ml}$. Serial ten-fold dilutions of the test material were added to the antigen-coated wells and incubated at $37^{\circ} \mathrm{C}$ for $2 \mathrm{~h}$. The wells, after washing, were filled with a solution of sheep anti-rabbit immunoglobulin conjugated with peroxidase (specific for rabbit $\operatorname{IgG}$ or $\operatorname{IgA}$ ) and incubated at $37^{\circ} \mathrm{C}$ for $2 \mathrm{~h}$. The plates were washed again and incubated for $10 \mathrm{~min}$ with the substrate-tetramethyl benzidine in dimethylsulphoxide and hydrogen peroxide. The reaction was stopped by adding sulphuric acid $(1 \mathrm{~N})$. The absorbance was measured at $450 \mathrm{~nm}$ in a Titertek Multiskan automatic plate reader (Flow Laboratories).

\section{Polyacrylamide gel electrophoresis ( $P A G E$ )}

PAGE in the presence of sodium dodecylsulphate (SDS) was performed by the method of King and Laemmli (1971). Briefly, the gel was cast between two plates $(15 \times 15 \mathrm{~cm})$ to a height of $10 \mathrm{~cm}$, with $1.0-\mathrm{cm}$ spacers. A stacking gel (acrylamide $3 \%$,w/v) $2 \mathrm{~cm}$ high was applied on top of the analytical gel. Electrophoresis was performed at $30 \mathrm{~mA}$. Individual LPS preparations $(1 \mathrm{mg})$ were dissolved in $1 \mathrm{ml}$ of sample buffer $(50 \mathrm{mM}$ Tris- $\mathrm{HCl} ; p \mathrm{H} 6 \cdot 8$; SDS $2 \%$; glycerol $10 \%$; bromphenol blue $0.1 \%$ ). After electrophoresis, the gel was stained by the periodic acid-schiff (PAS) reagent (Zacharius et al., 1969).

\section{Isoelectric focusing (IEF)}

IEF of cell-surface proteins and cholera toxin was performed in thin layer polyacrylamide gels, with ampholines in the $p \mathrm{H}$ range 3.5-9.5. The solutions for gel polymerisation were prepared as follows: (1) acrylamide $24 \mathrm{~g}$ and bisacrylamide $1 \mathrm{~g}$ made up to $100 \mathrm{ml}$; (2) $\mathrm{N}, \mathrm{N}, \mathrm{N}^{\prime}, \mathrm{N}^{\prime}$-tetramethylenediamine (TEMED) solution. $1.2 \mathrm{ml}$ diluted to $100 \mathrm{ml}$ in water; (3) ammonium persulphate $85 \mathrm{mg}$ dissolved in $100 \mathrm{ml}$ of water; (4) agarose $1 \%$ in water held at $60^{\circ} \mathrm{C}$. A $5-\mathrm{ml}$ volume of acrylamide solution was mixed with $1.875 \mathrm{ml}$ of ampholine, $0.5 \mathrm{ml}$ of TEMED solution, $15.125 \mathrm{ml}$ of ammonium persulphate and $2.5 \mathrm{ml}$ of agarose $1 \%$. The gel mixture was cast between two glass plates separated by a rubber gasket $1 \mathrm{~mm}$ thick; polymerisation was complete in $1 \mathrm{~h}$. IEF was performed on a flat bed (LKB) cooled to $5^{\circ} \mathrm{C}$ with the anode and cathode wicks saturated with $1 \mathrm{M}$ $\mathrm{H}_{3} \mathrm{PO}_{4}$ and $1 \mathrm{M} \mathrm{NaOH}$ respectively. Proteins $(75 \mu \mathrm{g})$ were focused at a constant power of $25 \mathrm{~W}$ for $1 \mathrm{~h}$. To stain for proteins the gel was fixed in a solution of tricholoroacetic acid $12 \%$ for $24 \mathrm{~h}$ and stained for $2 \mathrm{~h}$ in Coomassie brilliant blue $2.5 \%$ in methanol $40 \%$-acetic acid $10 \%$ and destained in methanol $40 \%$-acetic acid $10 \%$.

\section{Electrophoretic transfer of proteins and LPS from acrylamide gels to nitrocellulose sheets}

Proteins. Cell-surface proteins and cholera toxin resolved on polyacrylamide gels by IEF were transferred electrophoretically to nitrocellulose sheets. The gels were equilibrated with a buffer containing SDS $2.3 \mathrm{~g}$, glycerol $8 \mathrm{ml}$, Tris $0.75 \mathrm{~g}$ and $\mathrm{H}_{2} \mathrm{O} 90 \mathrm{ml}$, (the $p \mathrm{H}$ adjusted to 6.8 with $\mathrm{HCl}$ ) at room temperature with shaking for $1 \mathrm{~h}$. The proteins were then transferred to nitrocellulose membrane filters by electrophoresis at $25 \mathrm{~V}$ for $18 \mathrm{~h}$ in $25 \mathrm{~mm}$ Tris$192 \mathrm{~mm}$ glycine ( $p \mathrm{H} 8 \cdot 3)$-methanol $20 \%$-SDS $0 \cdot 1 \%$.

LPS. After SDS-PAGE, LPS was transferred electrophoretically from polyacrylamide gels to nitrocellulose sheets at $25 \mathrm{~V}$ for $18 \mathrm{~h}$ in $25 \mathrm{~mm}$ Tris-192 mM glycine $(p \mathrm{H}$ 8.3)-methanol $20 \%$-SDS $0 \cdot 1 \%$.

The electrophoretic blots containing proteins or LPS were developed as follows. The blot was soaked in bovine serum albumin $3 \% \mathrm{w} / \mathrm{v}$ in Tween buffer $(\mathrm{NaCl} 0.9 \% \mathrm{w} / \mathrm{v}$; $10 \mathrm{~mm}$ Tris- $\mathrm{HCl}, p \mathrm{H} \mathrm{7.4;} 155 \mathrm{~mm} \mathrm{NaCl}$; Tween $200.5 \%$ $\mathrm{w} / \mathrm{v})$. It was then incubated for $1 \mathrm{~h}$ with $5 \mathrm{ml}$ of serum from immunised rabbits diluted 1 in 100 in Tween buffer. The blot was washed extensively with Tween buffer, incubated for $1 \mathrm{~h}$ with horseradish peroxidase-conjugated IgG preparations and washed again as described above. The colour was developed by soaking the blot in a solution containing dioctyl sodium sulphosuccinate $0 \cdot 2 \%$, tetramethyl-benzidine $0.06 \%, \mathrm{H}_{2} \mathrm{O}_{2} 0.02 \% \mathrm{v} / \mathrm{v}, 5 \mathrm{mM}$ citric acid, $10 \mathrm{mM} \mathrm{Na} \mathrm{HPO}_{4}, p \mathrm{H} \mathrm{5.0.} \mathrm{The} \mathrm{reaction} \mathrm{was}$ terminated after $5 \mathrm{~min}$ by washing with water.

Control blots were run with preimmune sera from rabbits.

\section{Determination of neuraminidase activity}

The intestinal fluid from a rabbit with clinical cholera was filtered through a membrane filter $(0.45 \mu \mathrm{m}$; Millipore) and dialysed against $0 \cdot 1 \mathrm{M}$ acetate buffer $(p \mathrm{H} \mathrm{5.5)}$ containing $0.02 \mathrm{M} \mathrm{CaCl}_{2}$ for $48 \mathrm{~h}$ at $4^{\circ} \mathrm{C} ; 0.2-\mathrm{ml}$ volumes of the dialysed fluid were incubated with $0.1 \mathrm{ml}$ of a solution of bovine submaxillary mucin $(10 \mathrm{mg} / \mathrm{ml}$; Sigma). The final volume of the reaction mixture was brought to $0.5 \mathrm{ml}$ with $0.1 \mathrm{M}$ sodium acetate buffer $(p \mathrm{H}$ $5.5)$ containing $0.02 \mathrm{M} \mathrm{CaCl}_{2}$. The amount of $\mathrm{N}$ acetylneuraminic acid released was determined by the thiobarbituric acid method of Aminoff (1961). The intestinal fluid from an adult rabbit with no symptoms of diarrhoea was used as a control.

\section{Results}

\section{Agglutination studies}

The ability of serum, bile and intestinal samples (saline washes, citrate and tissue extracts) to agglutinate four $V$. cholerae strains after a single intra-duodenal inoculation with $10^{5}$ live $V$. cholerae C5 (Ogawa, el tor) is shown in fig. 1. All samples examined agglutinated strains of $V$. cholerae belonging to both biotypes (classical and el tor) and both serotypes (Ogawa and Inaba). Serum samples had high agglutination titres (32-64) one week after immunisation. The agglutination titres began to 
(a) Sera

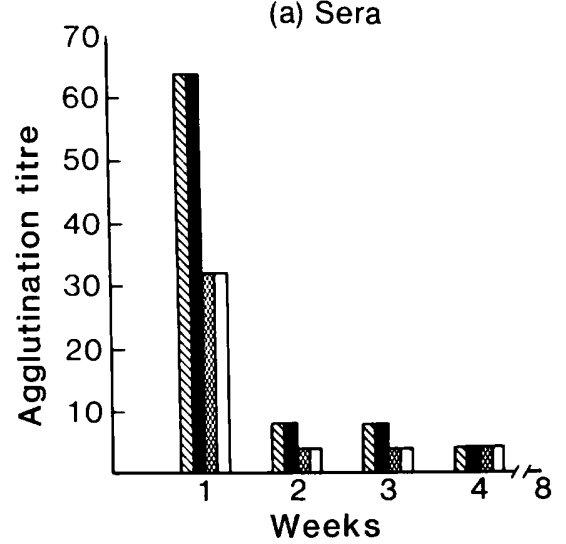

(c) Intestinal tissue extract

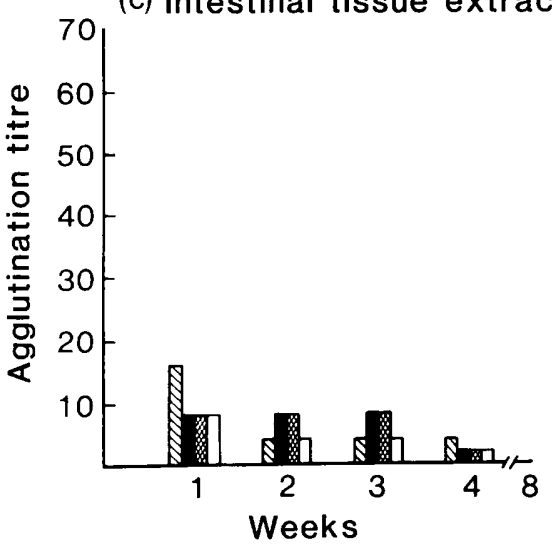

(b) Bile

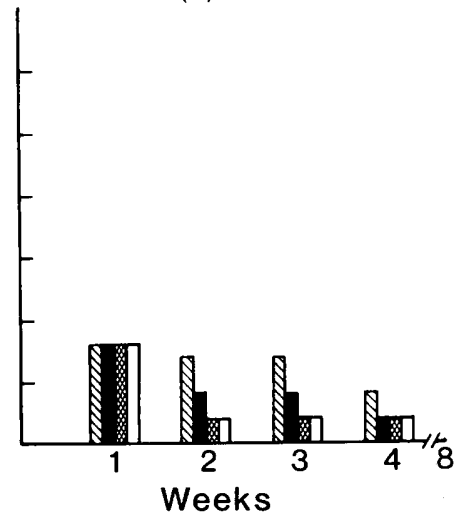

(d) Intestinal citrate extract

(e) Intestinal saline wash

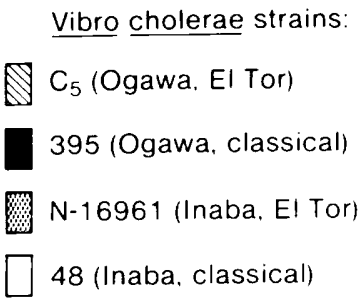

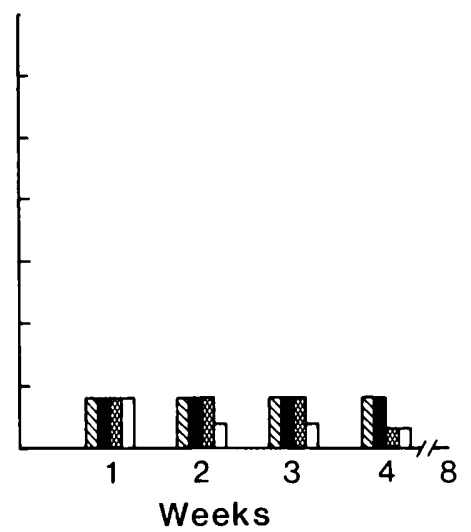

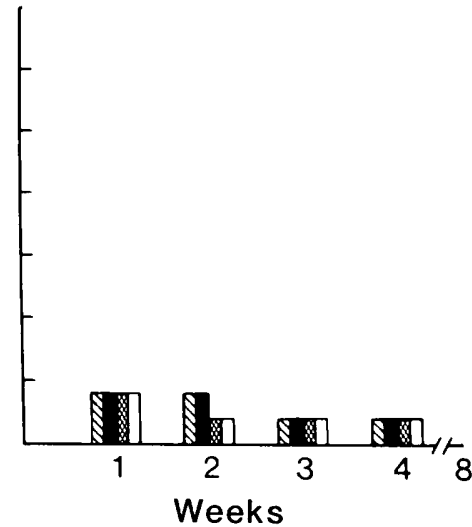

Fig. 1. The kinetics of appearance of agglutinating antibodies in various body fluids of rabbits after intra-duodenal inoculation of live $V$. cholerae $\mathrm{C} 5$ (Ogawa, el tor) cells. Two rabbits were used at each time point.

fall by the end of the second week, although some agglutinating activity remained to the end of the fourth week. By the end of the eighth week, the agglutinating titres had almost fallen to the background level. The intestinal tissue extracts (C) had higher agglutinating activities than those detected in saline (A) and citrate (B) extracts. Very little activity was observed by the end of the eighth week. In bile there was agglutinating activity (titre 16) against $V$. cholerae strains of all types one week after the inoculation. Strong agglutinating activity persisted for 3-4 weeks. At the end of the eighth week very little activity was observed.

To determine whether agglutinating activity was due to immunisation, control samples were also studied. Sera were collected from rabbits before immunisation. For practical reasons, bile and intestinal specimens (saline washings, citrate and tissue extracts) were collected from unimmunised rabbits only. Control serum and intestinal samples did not have any agglutinating activity towards any
$V$. cholerae strain. However, undiluted control bile did have some agglutinating activity. This activity was approximately eight-fold lower than that found in the bile from immunised animals.

\section{Immune responses to cell surface proteins}

Antibodies were present in all the body fluids against cell-surface proteins of $V$. cholerae strain C5 (fig. 2). A high titre was recorded in sera obtained at the end of the first week and was maintained for some time. Both IgG and IgA isotypes were detected although there was a higher proportion of IgG. Rabbit sera obtained 8 weeks after intra-duodenal inoculation also contained both IgG and IgA isotypes although IgG predominated. Antibodies to cell-surface proteins were present in bile by the end of the first week. The high titre was maintained in rabbits until the end of the fourth week. Very little antibody was detected by the end of the eighth week. 

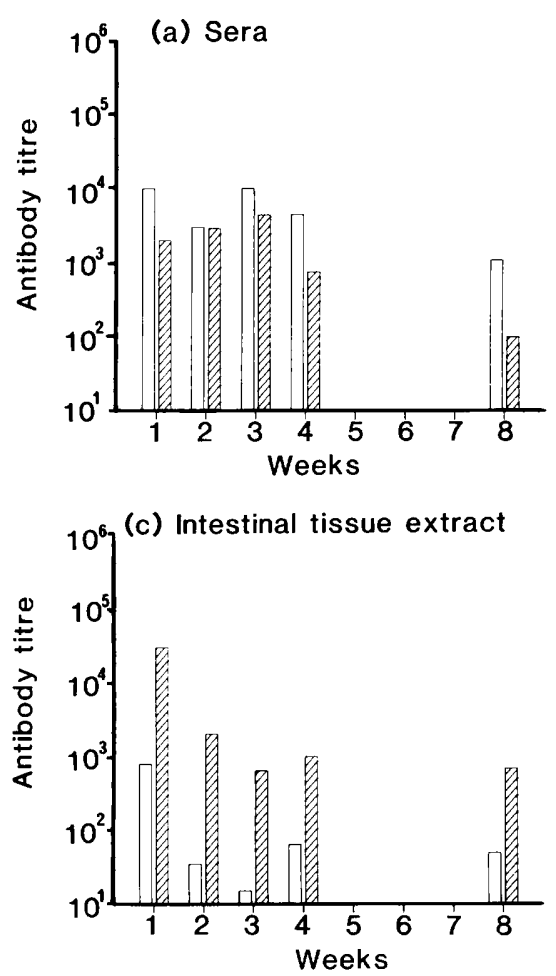

(b) Bile
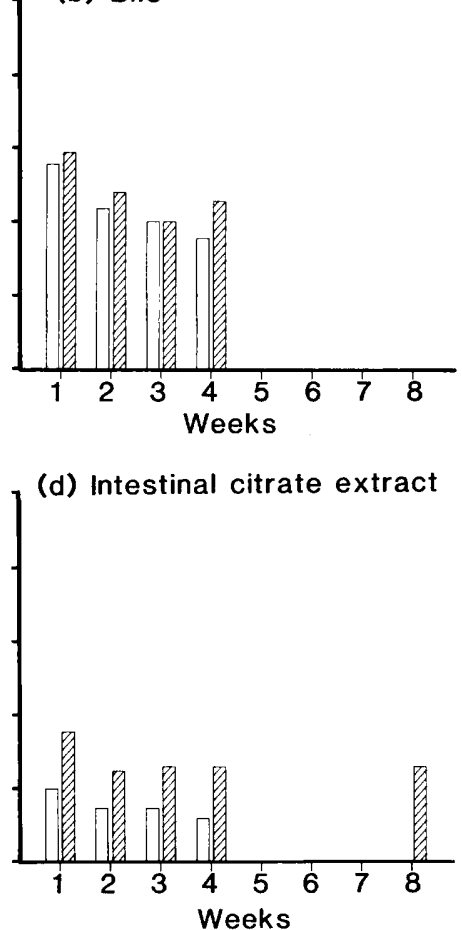

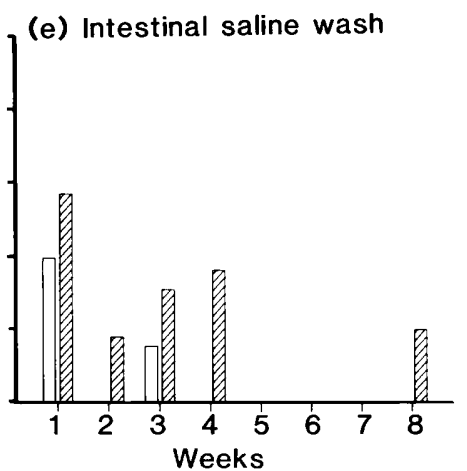

Fig. 2. Antibody responses to cell-surface proteins in various body fluids of rabbits 1-8 weeks after intra-duodenal inoculation of live $V$. cholerae $\mathrm{C} 5$ (Ogawa, el tor). Two rabbits were used at each point. ELISA was performed in microtitration plates. An $\mathrm{A}_{450}$ value $>0.1$ was considered to be positive. Each value represents the arithmetic mean of three readings.

Antibodies (predominantly $\operatorname{IgA}$ ) to cell-surface proteins were present in all the intestinal samples. The approximate $\mathrm{IgG}: \operatorname{IgA}$ ratios by the end of the first week after inoculation, in each intestinal sample, were 1:30 (tissue extract), 1:6 (citrate extract) and 1:7 (saline wash). Significant $\operatorname{IgA}$ levels were detected in these fluids even 8 weeks after challenge. Very little IgG was detected by that time.

Serum, bile and intestinal samples from uninoculated control animals did not contain any detectable immunoglobulins to cell-surface proteins of $V$. cholerae.

\section{Immunological responses to LPS}

Because the rabbits had been infected with a strain of the Ogawa serotype, Ogawa LPS was used to follow the kinetics of immune response in various body fluids. As shown in fig. 3, immunoglobulins against LPS were detected in all the body fluids examined. There was a higher ratio of $\operatorname{IgG}: \operatorname{IgA}$ in serum than in the other samples and the titre was maintained longer. Saline washes contained predominantly IgA antibodies to LPS. Very little IgG was detected. Similarly both the citrate and the tissue extracts contained $\operatorname{IgA}$ antibodies as well as some IgG antibodies. There was a high level of anti-LPS of both IgG and IgA isotype in bile; IgA antibodies predominated and the titre was maintained for 4 weeks. Very little of these immunoglobulins were detected 8 weeks after immunisation.

\section{Immunological responses to cholera toxin}

Antibodies to cholera toxin were present in all the samples examined (fig. 4). The titres of antitoxin antibodies (both IgG and IgA) in serum were maintained for up to 8 weeks. There were high titres of $\operatorname{IgA}$ antibodies but no $\operatorname{IgG}$ antibodies to cholera toxin in bile. This antibody was detected even 8 weeks after immunisation. Saline washes of the intestine contained antibodies to cholera toxin of IgA isotype only. Citrate and tissue extracts contained both $\operatorname{IgA}$ and $\operatorname{IgG}$ antibodies, although IgA predominated.

\section{Immunological responses to neuraminidase}

All the samples (sera, bile and intestinal speci- 

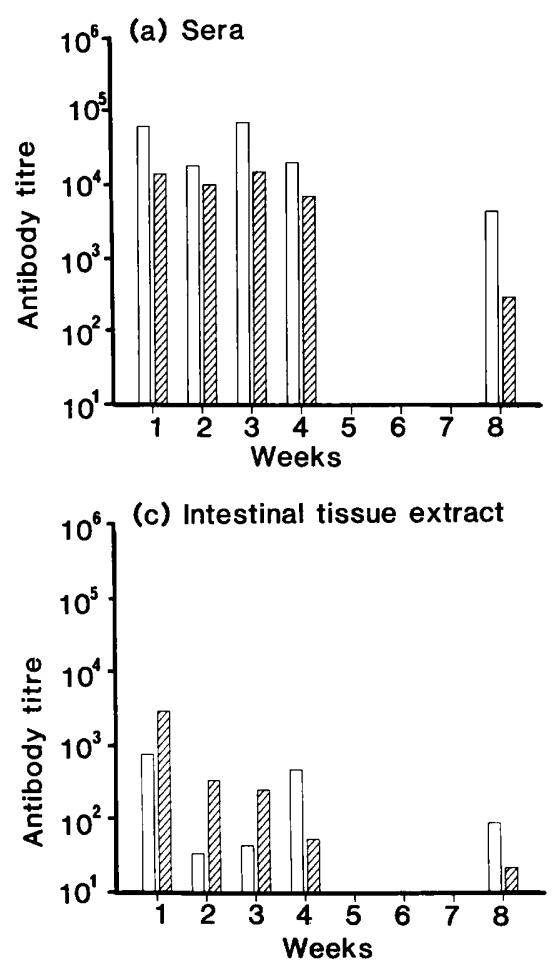

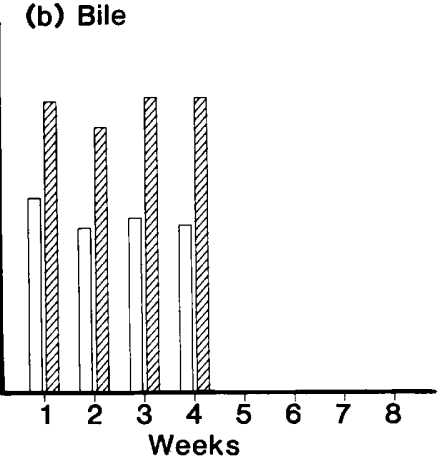

(d) Intestinal citrate extract

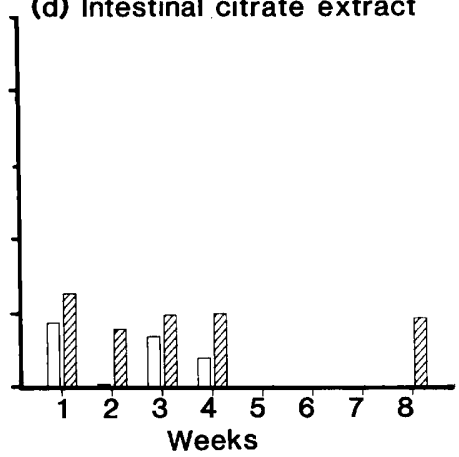

(e) Intestinal saline wash

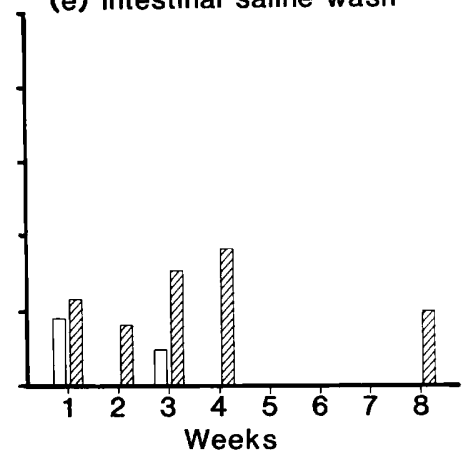

Fig. 3. Antibody responses to LPS (Ogawa) in various body fluids of rabbits 1-8 weeks after intra-duodenal inoculation of $V$. cholerae C5 (Ogawa, el tor). Two rabbits were used at each point. ELISA was performed in microtitration plates. An $A_{450}$ value $>0.1$ was considered to be positive. Each value represents the arithmetic mean of three readings.
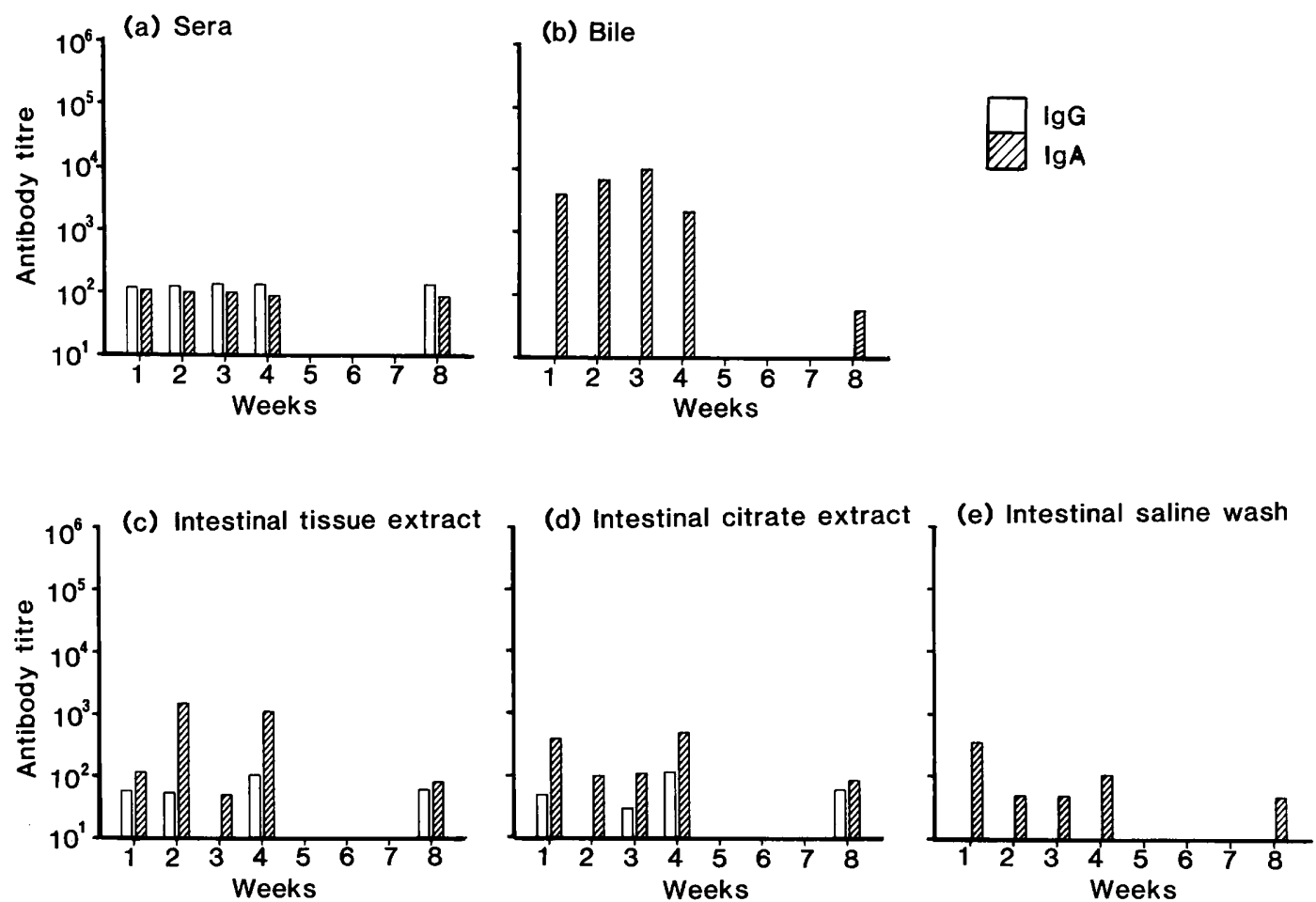

Fig. 4. Antibody responses to cholera toxin in various body fluids of rabbits 1-8 weeks after intra-duodenal inoculation of live $V$. cholerae C5 (Ogawa, el tor). Two rabbits were used at each point. ELISA was performed in microtitration plates. An $A_{450}$ value $>0.1$ was considered to be positive. Each value represents the arithmetic mean of three readings. 
mens) obtained from the rabbits inoculated with $V$. cholera contained antibodies to neuraminidase (fig. 5). IgG antibodies were detected in sera of all the rabbits even after 8 weeks. However, IgA antibodies to neuraminidase were found in rabbits killed 2-3 weeks after duodenal inoculation. Only IgA antibodies to neuraminidase were detected in the bile and the titre was maintained even 8 weeks after inoculation. Intestinal saline washings contained only $\operatorname{IgA}$ antibodies and the titre was maintained even 8 weeks after inoculation. The citrate extract contained IgA and IgG antibodies for 8 weeks. The tissue extract contained high-titre IgG and IgA antibodies.

\section{Immunological responses to common somatic} antigens of $V$. cholerae

$V$. cholerae strains of both biotypes and both serotypes share cross-reacting antigens. To determine the nature of the common antigens, immune responses to $V$. cholerae LPS from both serotypes (Ogawa and Inaba) were measured in the rabbit model. Cell-surface proteins from two heterologous strains (Ogawa, el tor and Inaba, classical) were used. V. cholerae C5 (Ogawa, el tor) was inoculated into rabbits as before. As shown in fig. 6, high-titre antibodies to cell-surface proteins were found in sera, bile, intestinal washes, citrate and tissue extracts, irrespective of the biotype and serotype tested. When homologous Ogawa LPS was used as the coating antigen in ELISA, high-titre antibodies (both IgG and IgA) to LPS, were detected in all the biological fluids tested. When Inaba LPS was used as the coating antigen, very little antibody activity was detected in the sera. Although antibodies to the Inaba LPS were detected in bile and in intestinal specimens, the titres were much lower than those found against the Ogawa LPS.

\section{Detection of antibody to $V$. cholerae LPS in immune sera by immunoblotting}

To obtain visual evidence of the presence of antibodies to $V$. cholerae LPS, immunoblotting studies were performed. $V$. cholerae LPS from both serotypes (Ogawa and Inaba) were first separated by PAGE in the presence of SDS (fig. 7). Ogawa LPS produced two bands, detected by the polysaccharide-specific staining reagent periodic acidSchiff base; one migrated slowly, the other faster. Inaba LPS produced one broad band on the gel, (a) Sera
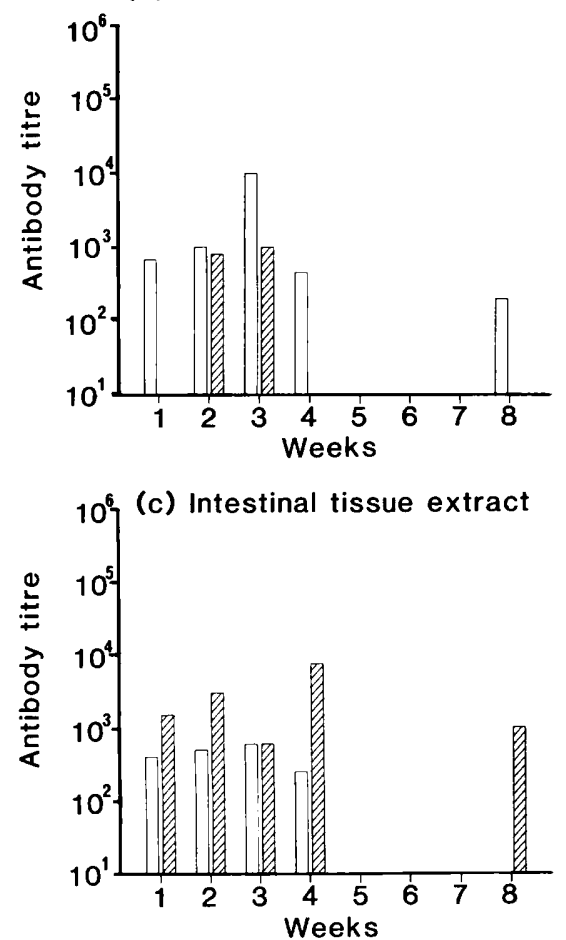

(b) Bile
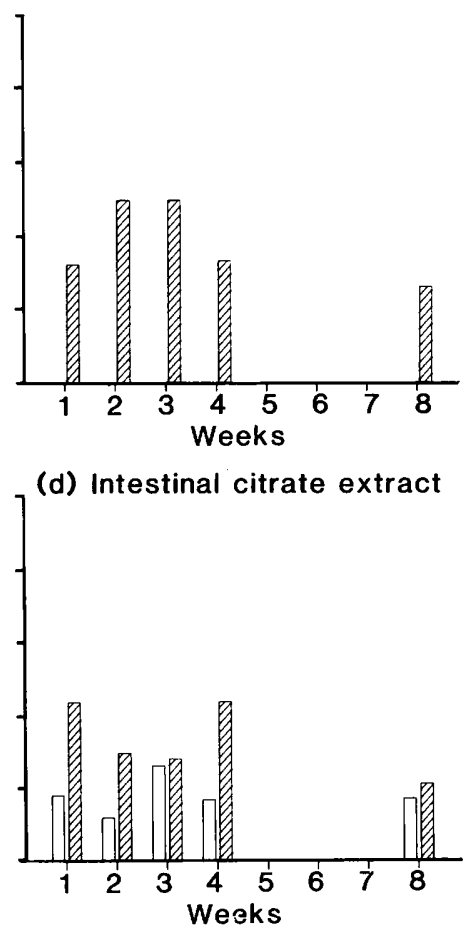

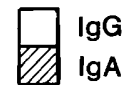

(e) Intestinal saline wash

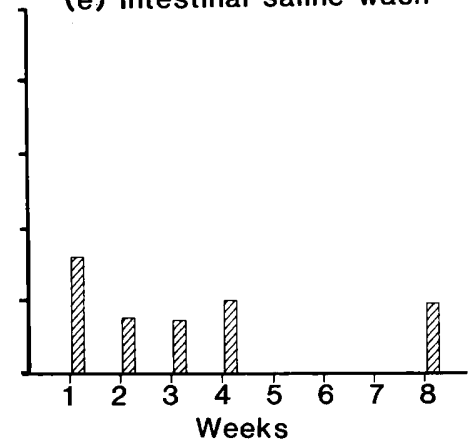

Fig. 5. Antibody responses to $V$. cholerae neuraminidase in various body fluids of rabbits $1-8$ weeks after intra-duodenal immunisation. Two rabbits were used at each point. ELISA was performed in microtitration plates. An $A_{450}$ value $>0.1$ was considered.$o$ be positive. Each value represents the arithmetic mean of three separate readings. 

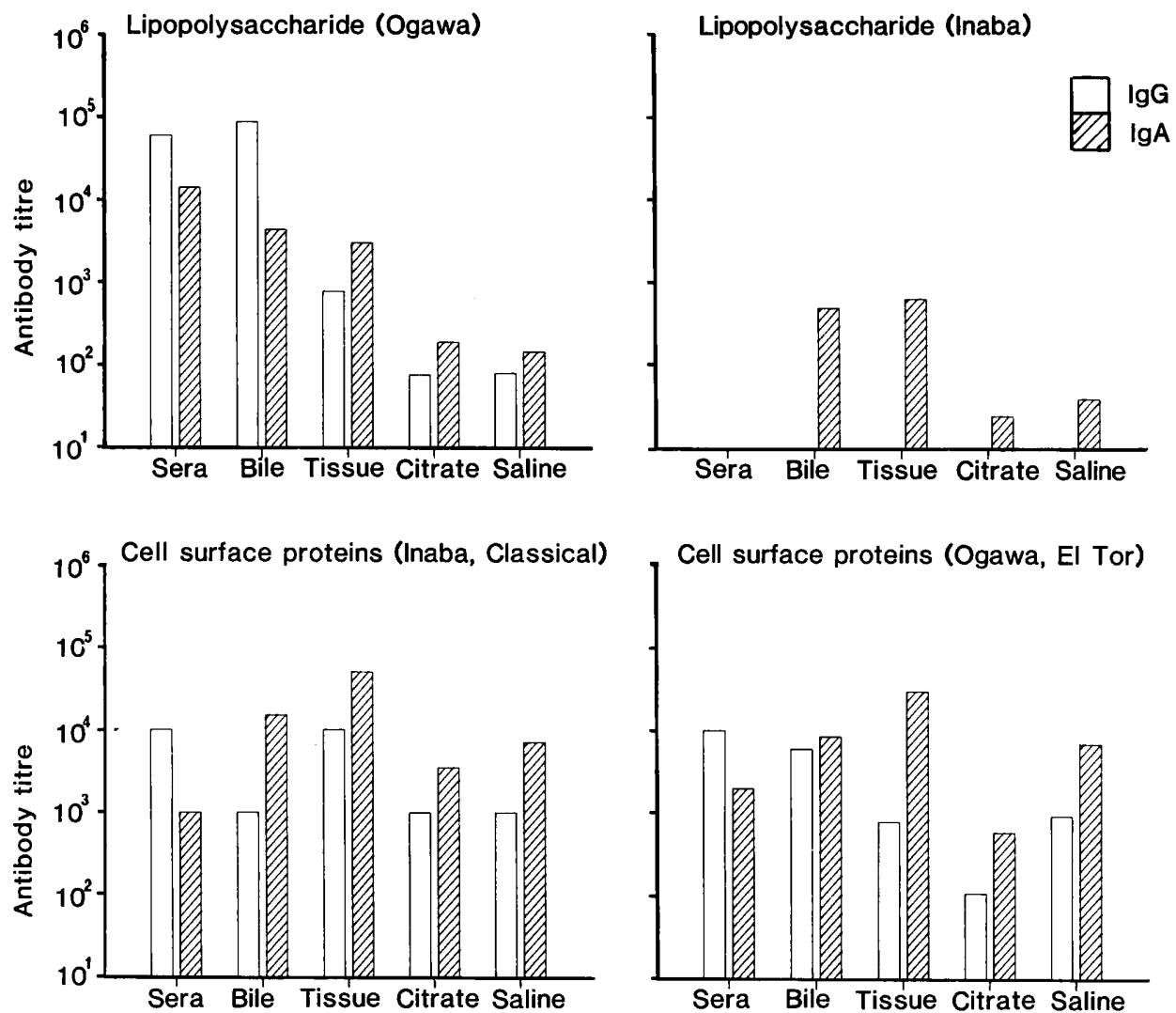

Fig. 6. Antibody responses to LPS (Ogawa and Inaba) and cell-surface proteins (Inaba, classical; Ogawa, el tor) in various body fluids 1 week after intra-duodenal inoculation of live $V$. cholerae C5 (Ogawa, el tor). Two rabbits were used at each point. ELISA was performed in microtitration plates. An $A_{450}$ value $>0.1$ was considered to be positive. Each value represents the arithmetic mean of three separate readings.

close to the fast migrating band of the Ogawa LPS. Negatively charged polysaccharide moieties were transferred to the nitrocellulose membrane by transblot electrophoresis. The blot was overlaid with the immune sera. Only one fraction of the Ogawa LPS was reactive (fig. 8). The Inaba LPS did not produce any visible reaction with the immune sera.

Detection of antibody to cell-surface proteins of $V$. cholerae in the immune sera by immunoblotting

To obtain visual evidence for the presence of antibodies to cell-surface proteins in the immune sera, a combination of techniques involving isoelectric focusing and subsequent electrophoretic transfer to a nitrocellulose sheet were applied. Cell surface proteins were first subjected to isoelectric focusing on a polyacrylamide gel. One part of the gel was stained for protein with Coomassie brilliant blue and the other part was subjected to transblot electrophoresis to transfer proteins to a nitrocellu- lose sheet. Incubation of the blot with the sera and subsequent treatment with a second antibody conjugated to peroxidase revealed the presence of several immunogenic protein bands. When the cellsurface proteins alone were subjected to isoelectric focusing and stained with Coomassie brilliant blue, the proteins focused between $p \mathrm{H} 4$ and 7 (fig. 9a). A strong band was observed at $p \mathrm{H} 6 \cdot 25$, a broad band at $5 \cdot 75$, two sharp bands around 5.6-5.5, one faint band at $5 \cdot 1$ and two faint bands at $p \mathrm{H} 4.6$ and 4.9. The isoelectric focusing nitrocellulose blot showed the presence of a broad band representing proteins with isoelectric points between $p \mathrm{H} 5$ and 6 (fig. 9b). Two strong bands, a little above $p \mathrm{H} \mathrm{7,}$ were detected on the blot. These were not visible when the gel was stained with the Coomassie brilliant blue.

Detection of antibody to cholera toxin in the immune sera by immunoblotting

To obtain visual evidence of the presence of 


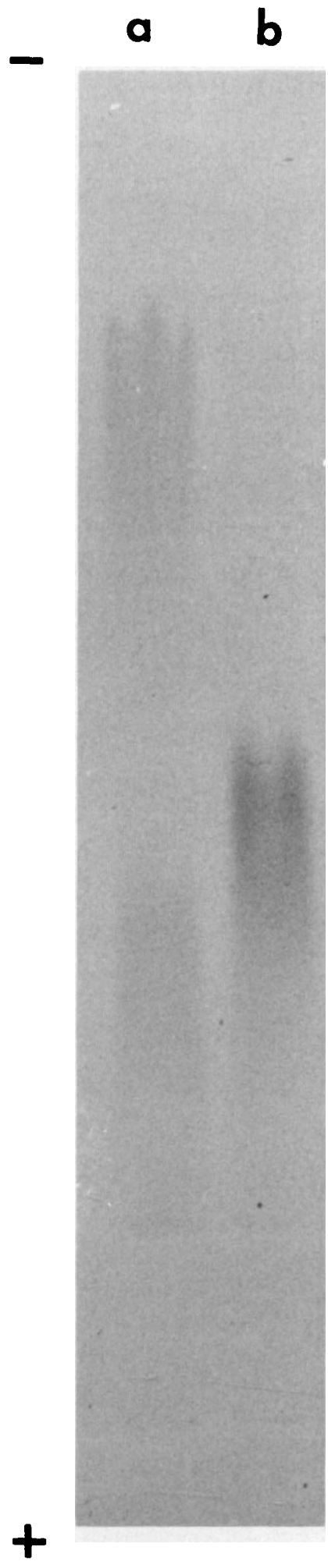

Fig. 7. Sodium dodecyl sulphate-polyacrylamide gel electrophoresis (SDS-PAGE) of LPS preparations from $V$. cholerae. Gels were stained for carbohydrate moieties by the periodic acidSchiff reagent. (a) LPS from $V$. cholerae 395 (Ogawa); (b) LPS from $V$. cholerae 569B (Inaba).

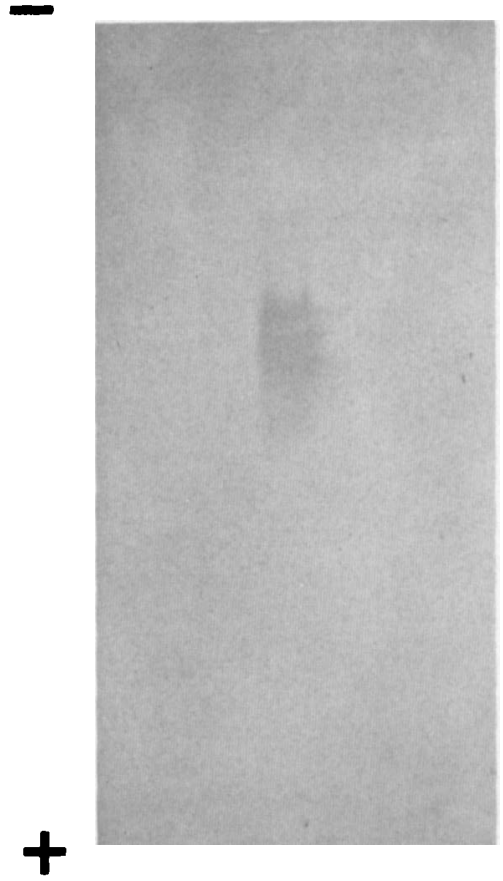

Fig. 8. Immunoblot reactivity of sera from rabbits after intraduodenal inoculation of $V$. cholerae LPS (Ogawa) $(5 \mu \mathrm{g})$ separated by SDS-PAGE was transferred electrophoretically to the nitrocellulose membrane. The blot was developed by ELISA.

antibodies to cholera toxin in the immune sera, immunoblotting studies were performed. Cholera toxin was separated by isoelectric focusing on a polyacrylamide gel. One part of the gel was stained for protein with Coomassie brilliant blue and the other part was subjected to transblot electrophoresis. The intact cholera toxin was resolved into several bands in the $p \mathrm{H}$ range $6.5-6.8$ indicating charge heterogeneity (fig. 10a). Because cholera toxin contained a little of the free B subunit, as stated by the supplier, a few minor bands corresponding to the $\mathrm{B}$ subunit were observed in the $p \mathrm{H}$ range $7 \cdot 2-7 \cdot 5$. After incubating the blot with the immune sera and then performing ELISA on the blot, a broad band in the $p \mathrm{H}$ range $6 \cdot 5-6.8$, representing intact cholera toxin, was observed. Two minor bands in the $p \mathrm{H}$ range 7.4-7.5 representing the B subunits were also observed (fig. 10b).

\section{Discussion}

In this study, rabbits were given a single intraduodenal inoculation of live $V$. cholerae cells and the kinetics of immune responses to various antigens (LPS, cell-surface proteins, cholera toxin and neuraminidase) in various body fluids were examined. Although intestinal lavages have been used to study cholera immunology (Svennerholm et al., 1984), these materials cannot represent the true 


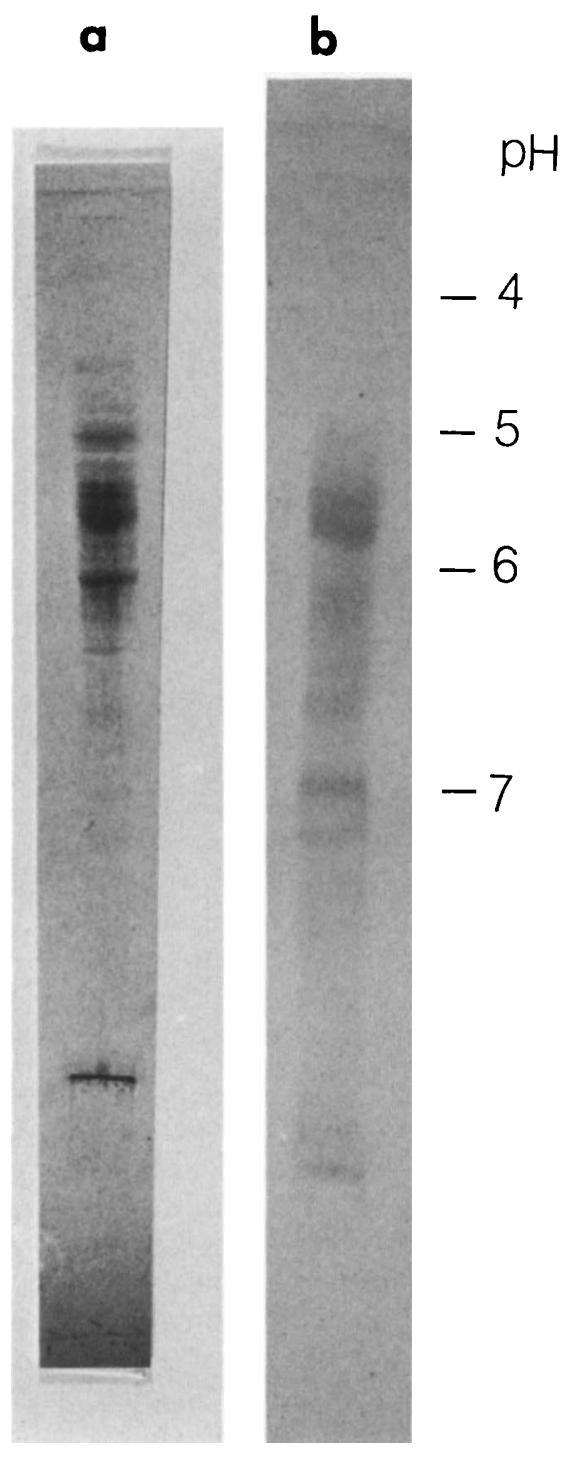

Fig. 9. (a) Separation of cell-surface proteins of $V$. cholerae $\mathrm{C5}$ (Ogawa, el tor) by isoelectric focusing in 1-mm polyacrylamide gels. Conditions: $25 \mathrm{~W}, 1 \mathrm{~h}$, ampholyte range $p \mathrm{H} 3 \cdot 5-9 \cdot 5$. Sample: $15 \mu \mathrm{l}$ containing $75 \mu \mathrm{g}$ of protein. The gel was stained for protein with Coomassie brilliant blue R-250. (b) Immunoblot reactivity to cell surface proteins of $\boldsymbol{V}$. cholerae $\mathrm{C} 5$ of sera from rabbits after intra-duodenal inoculation with $V$. cholerae $\mathrm{C} 5$ (Ogawa, el tor). Proteins were separated by isoelectric focusing in $1-\mathrm{mm}$ polyacrylamide gels and transferred to the nitrocellulose membrane electrophoretically. The blot was developed by ELISA

level of immunoglobulins in the gut after an antigenic stimulus. Therefore, in this investigation, antibody titres were measured in intestinal secretions and in extracts from intestinal tissues underlying the epithelium. Various body fluids (serum, bile and intestinal samples) of the rabbits contained (i) agglutinins against $V$. cholerae strains belonging to both biotypes and both serotypes, and (ii) antibodies to both the secreted (cholera toxin and neuraminidase) and the cell bound (LPS and surface protein) components of $V$. cholerae. Bile and intestinal samples had high IgA titres; sera had a higher proportion of IgG.

Levine et al. (1984) observed that only $12 \%$ of human volunteers recorded a rise in antitoxin titre when fed live $V$. cholerae cells. A rise in antibody titre to LPS and outer-membrane proteins was recorded in only $29 \%$ of vaccinees. These authors used polyvinylchloride intestinal tubes to collect jejunal fluid for measuring intestinal antibodies. This isolation procedure may not have been sensitive enough for collecting immunoglobulins from human volunteers because intestinal antibodies can be associated with intestinal mucins (Walker et al., 1977). In the present study, all the rabbits

\section{(a)

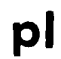 \\ (b) pl}
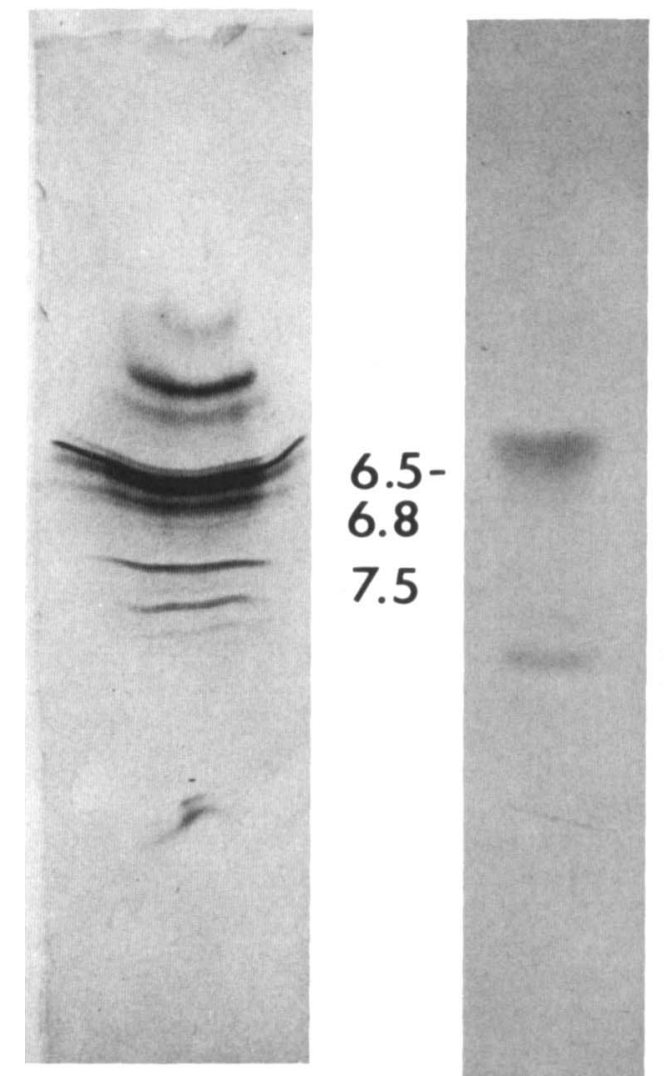

$6.5-$ 6.8

7.5

Fig. 10. (a) Separation of cholera toxin by isoelectric focusing in 1-mm polyacrylamide gels. Conditions: $25 \mathrm{~W}, 1 \mathrm{~h}$, ampholyte pH 3.5-9.5. Sample: $15 \mu$ l containing $75 \mu \mathrm{g}$ of protein. The gel was stained for protein with Coomassie brilliant blue R-250. (b) Immunoblot reactivity to cholera toxin of sera from rabbits after intra-duodenal immunisation with $V$. cholerae C5 (Ogawa, el tor). Proteins were separated by isoelectric focusing in 1-mm polyacrylamide gels and transferred to the nitrocellulose membrane electrophoretically. The blot was developed by ELISA. 
contained a significant level of antibodies against $V$. cholerae antigens such as LPS, cell surface proteins, cholera toxin and neuraminidase. Rabbit intestinal tissues were thoroughly washed and, by further extraction, greater amounts of $\operatorname{IgA}$ were demonstrated in these extracts than were detected in intestinal saline washes.

Guinée et al. (1985) observed that rabbits given a single intra-duodenal dose of live $V$. cholerae were protected for several weeks against homologous and heterologous challenges. In the present study, antibodies against various $V$. cholerae components were found to be present in the intestine several weeks later. Guinée et al. (1985) could not cultivate any $V$. cholerae from intestinal fluid or stool of challenged rabbits even several weeks after a single duodenal inoculation. This led them to believe that antibacterial processes were taking place in the gut. Earlier, Fubara and Freter (1973) reported that IgA from rabbits immunised with $V$. cholerae could protect rabbits from experimental cholera, but these studies did not preclude the possibility that antibodies of other isotypes might have been involved in protection because these authors had used a less sensitive Farr test to detect immunoglobulin isotypes. We used ELISA and observed that all the intestinal samples contained IgG directed against cell-surface components such as LPS and proteins. Because intestinal IgG fixes complement (O'Daly and Cebra, 1971), IgG might have contributed to intestinal bactericidal activity.

The present investigation demonstrated that cellsurface proteins were major common somatic antigens of $V$. cholerae. Although rabbits were given strain C5 (Ogawa, el tor), their body fluids contained high titres of $\operatorname{IgG}$ and $\operatorname{IgA}$ antibodies against cell-surface proteins, irrespective of biotype and serotype. The immunoglobulins showed much reduced activity towards LPS from a heterologous Inaba strain. Only IgA, at a much reduced level, was detected in bile and intestinal samples and showed no cross-reaction with Inaba LPS.

In this investigation a combination of techniques, including isoelectric focusing and electrophoretic transfer to nitrocellulose membrane, was used to detect immunogenic proteins. In commonly used protein blotting techniques, proteins are separated on polyacrylamide gels after disaggregation by heating in SDS and are then transferred to nitrocellulose membranes. However, cell-surface proteins from gram-negative bacteria are sensitive to heating in the presence of SDS (Rosenbusch, 1974; Reithmeier and Bragg, 1977; Kabir, 1980). Therefore, the milder non-denaturating but still powerful, analytical technique of isoelectric focus- ing was used to separate proteins. Proteins transferred from isoelectrically focused gels retained the ability to bind to the immune sera. These results provide visual evidence of the immunogenicity of cell-surface proteins of $V$. cholerae. Major proteins detected by Coomassie staining were also detected on the nitrocellulose blot. Furthermore, two strong bands around $p \mathrm{I} 7$ were detected on the nitrocellulose blot which were not detected by the Coomassie staining. This indicates that immunoblotting after isoelectric focusing is a sensitive technique for detecting immunogenic proteins.

When cholera toxin was analysed by isoelectric focusing on thin layer polyacrylamide gels, it was resolved into several bands indicating charge heterogeneity. Major bands focused around $p \mathrm{I} 6 \cdot 8$. Because, in non-denaturing conditions, both $A$ and B subunits are strongly held together, cholera toxin produced a major band thus providing visual evidence of the presence of antitoxin antibodies in the immune sera. Antibodies to the free B subunit were also detected. This is because $V$. cholerae cells, after duodenal inoculation, proliferate in the gut and liberate cholera toxin and the free $B$ subunit that interact with lymphoid cells to produce antibodies.

In this investigation it was found that diarrhoeal fluids from the infected rabbits contained neuraminidase. Antibodies to neuraminidase were also detected in all the samples (sera, bile and intestinal) tested. Although cholera toxin is the cause of diarrhoea, the role of neuraminidase in the pathogenicity of $V$. cholerae has not been established. It may play a role in the induction of the disease. The enzyme splits off terminal neuraminic acids of glycoproteins and glycolipids (Drzeniek, 1972). When acting on gangliosides, it removes sialyl residues from major oligogangliosides, giving rise to monosialoganglioside $\mathrm{GM}_{1}$ which is resistant to further enzyme action. $\mathrm{GM}_{1}$ is the receptor for cholera toxin (Cuatrecasas, 1973; van Heyningen, 1974). Staerk et al. (1974) observed that when canine intestinal loops were pretreated with neuraminidase, there was an increase in the output of fluid after incubation with cholera toxin. It is likely that neuraminidase may attack intestinal glycoproteins and gangliosides, unmasking receptor sites for cholera toxin. By neutralising the enzyme, antibodies to neuraminidase may hinder the action of cholera toxin.

At present there is a need for a cholera vaccine that is safe for use in man. It should produce immunity against both biotypes and both serotypes of $V$. cholerae. Because cholera is a toxin-mediated disease, nontoxigenic $V$. cholerae strains have been 
constructed by molecular genetic techniques (Kaper et al., 1984). Although the gene for cholera toxin had been deleted from such strains, mild to moderate diarrhoea still occurred when volunteers were fed these strains (Kaper et al., 1984). The illness may have been due to other still poorly characterised toxins produced by the organisms (Sanyal et al., 1983). At present very few options are left for the development of a safe cholera

\section{REFERENCES}

Ada G L, French E L, Lind P E 1961 Purification and properties of neuraminidase from Vibrio cholerae. Journal of General Microbiology 24:409-421.

Aminoff D 1961 Methods for the quantitative estimation of $\mathrm{N}$ acetylneuraminic acid and their application to hydrolysates of sialomucoids. Biochemical Journal 81 : 384-392.

Burrows W, Musteikis G M, Oza N B, Dutta N K 1965 Cholera toxins: quantitation of the frog skin reaction and its relation to experimental enteric toxicity. Journal of Infectious Diseases 115: 1-8.

Cuatrecasas P 1973 Gangliosides and membrane receptors for cholera toxin. Biochemistry 12:3558-3566.

De S N, Chatterje D N 1953 An experimental study of the mechanism of action of Vibrio cholerae on the intestinal mucous membrane. Journal of Pathology and Bacteriology 66: $559-562$.

Drzeniek R 1972 Viral and bacterial neuraminidase. Current Topics in Microbiology and Immunology 59:35-74.

Evans D G, Evans D J, Gorbach S L 1973 Identification of enterotoxigenic Escherichia coli and serum antitoxin activity by the vascular permeability factor assay. Infection and Immunity 8:731-735.

Fubara E S, Freter R 1973 Protection against enteric bacterial infection by secretory IgA antibodies. Journal of Immunology 111 : $395-403$.

Guinée P A M, Jansen W H, Peters P W J 1985 Vibrio cholerae infection and acquired immunity in an adult rabbit model. Zentrablatt für Bakteriologie Mikrobiologie und Hygiene Series A 259: 118-131.

Kabir S 1980 Composition and immunochemical properties of outer membrane proteins of Vibrio cholerae. Journal of Bacteriology 144:382-389.

Kabir S 1982 Characterization of the lipopolysaccharide from Vibrio cholerae 395 (Ogawa). Infection and Immunity 38: 1263-1272.

Kabir S $1983 a$ The serological properties of the cell surface proteins of Vibrio cholerae. Journal of General Microbiology 129:2199-2206.

Kabir S $1983 b$ Immunochemical properties of the major outer membrane protein of Vibrio cholerae. Infection and Immunity 39:452-455.

Kabir S, Ahmad N, Ali S 1984 Neuraminidase production by Vibrio cholerae $\mathrm{O} 1$ and other diarrheagenic bacteria. Infection and Immunity 44:747-749.

Kaper J B, Lockman H, Baldini M M, Levine M M 1984 Recombinant nontoxinogenic Vibrio cholerae strains as attenuated cholera vaccine candidates. Nature 308:655658.

King J, Laemmli U K 1971 Polypeptides of the tail fibres of bacteriophage T4. Journal of Molecular Biology 62:465477. vaccine. An ideal attenuated vaccine strain should be devoid of factors contributing to enterotoxicity. Alternatively, a combination of non-viable immunogens such as cell-surface proteins, detoxified LPS coupled to a suitable carrier protein, and neuraminidase could be considered to be candidates for an effective vaccine.

This work was supported by a grant from the Prevention Fund, The Netherlands.

Levine M M et al. 1984 Evaluation in humans of attenuated Vibrio cholerae el tor Ogawa strain Texas Star-SR as a live oral vaccine. Infection and Immunity 43:515-522.

Lowry O H, Rosebrough N J, Farr A L, Randall R J 1951 Protein measurement with the Folin phenol reagent. Journal of Biological Chemistry 193:265-275.

Majumdar A S, Dutta P, Dutta D, Ghose A C 1981 Antibacterial and antitoxin responses in the serum and milk of cholera patients. Infection and Immunity 32: 1-8.

O’Daly J A, Cebra J J 1971 Rabbit secretory IgA. II. Free secretory component from colostrum and its specific association with IgA. Journal of Immunology 107:449-455.

Reithmeier R A F, Bragg P D 1977 Cross-linking of the proteins in the outer membrane of Escherichia coli. Biochimica Biophysica Acta 466: 245-256.

Rosenbusch J P 1974 Characterization of the major envelope protein from Escherichia coli. Journal of Biological Chemistry 249:8019-8029.

Sack D A, Huda S, Neogi P K B, Daniel R R, Spira W M 1980 Microtiter ganglioside enzyme-linked immunosorbent assay for vibrio and Escherichia coli heat-labile enterotoxins and antitoxin. Journal of Clinical Microbiology 11:35-40.

Sanyal S C, Alam K, Neogi P K B, Huq M I, Al-Mahmud K A 1983 A new cholera toxin. Lancet $\mathbf{I}: 1337$.

Spira W M, Sack R B, Froehlich J L 1981 Simple adult rabbit model for Vibrio cholerae and enterotoxigenic Escherichia coli diarrhea. Infection and Immunity 32:739-747.

Staerk J, Ronneberger H J, Wiegandt H 1974 Neuraminidase, a virulence factor in Vibrio cholerae infection? Behring Institut Mitteilungen 55:145-146.

Stern B K, Jensen W E 1966 Active transport of glucose by suspensions of isolated rat intestinal epithelial cells. Nature 209:789-790.

Svennerholm A M, Gothefors L, Sack D A, Bardhan P K, Holmgren J 1984 Local and systemic antibody responses and immunological memory in humans after immunization with cholera B subunit by different routes. Bulletin of the World Health Organization 62:909-918.

van Heyningen W E 1974 Gangliosides as membrane receptors for tetanus toxin, cholera toxin and serotonin. Nature 249:415-417.

Walker W A, Wu M, Bloch K J 1977 Stimulation by immune complexes of mucus release from goblet cells of the rat small intestine. Science 197:370-372.

Westphal O, Luderitz O, Bister F 1952 Uber die Extraktion von Bakterien mit Phenol-wasser. Zeitschrift fur Naturforschung B7: $148-155$.

Westphal O, Jann K 1965 Bacterial lipopolysaccharides. Extraction with phenol-water and further applications of the procedure. Methods in Carbohydrate Chemistry 5:83-91.

Zacharius R M, Zell T E, Morrison J H, Woodlock J J 1969 Glycoprotein staining following electrophoresis on acrylamide gels. Analytical Biochemistry 30: 148-152. 